\title{
(Isten)nők és Boccaccio
}

Giovanni Boccaccio, writing his prosaic works in Latin and researching antique and medieval literary sources, as a philologist faces the question of systematizing and evaluating of Greek-Roman goddesses: were they really goddesses or not? How can he reveal his point of view to his readers? What kind of concept stands out in Genealogia deorum gentilium, and how consciously and consistently he uses that later in De mulieribus claris? What are the similarities and the differences between the portraits of goddesses in these two works? This is a maze of Cereses and Minervas, and the reader himself has to find the way out of it. ${ }^{1}$

\section{Egy szerző, két mü, hat istennő}

Eltérő szerzői szándék, eltérő célközönség, ám mégis számos hasonlóság fedezhető fel abban, ahogyan Boccaccio az istennők alakjait kezelte két nagy, latin nyelvü prózai múvében, a Genealogia deorum gentiliumban (A pogány istenek genealógiája) és a De mulieribus clarisban (Híres hölgyekről). Hat, a görög-római mitológiai hagyományhoz köthető istennő, Ops, Iuno, Ceres, Minerva, Venus és Isis (utóbbi részben az egyiptomi hagyományhoz is kapcsolódik) alakja mindkét múben megjelenik. Milyen elveket követve, és milyen források alapján alkotta meg leírásaikat Boccaccio? Milyen koncepció rajzolódik ki a Genealogia deorum gentiliumban, és ez mennyire tudatos, következetesen alkalmazott később, a De mulieribus clarisban? Miben hasonlít,

${ }^{1}$ A publikáció elkészítését az MTA-SZTE Antikvitás és reneszánsz: források és recepció Kutatócsoport (TK2016-126) támogatta, a szerző az SZTE BTK Olasz Nyelvi és Irodalmi Tanszékének PhD-hallgatója és óraadója. 
vagy különbözik egy-egy istennő ábrázolása a két müben? Az összehasonlítás rávilágíthat a boccacciói forrásfeldolgozás és forrásfelhasználás jellegzetességeire, a Genealogia és a De mulieribus kapcsolatára, valamint Boccaccio összetett és sokrétü filológiai hozzáállására is. Továbbá hangsúlyozhatja annak szükségességét, hogy a szerző teljes életmüvét egységben kell vizsgálnunk, ez alól pedig latin nyelvű prózai müvei sem képeznek kivételt.

A két műben megfigyelhető eltérő és közös elemeket, illetve ezek lehetséges okait ez alkalommal Ceres alakján keresztül fogom bemutatni, a müvek megírásának sorrendje ${ }^{2}$ és az egyes hölgyekkel kapcsolatban általában közölt információk mennyisége miatt az ismertetést a Genealogiával kezdve.

Mielőtt azonban a konkrét példa bemutatására kerülne sor, szükséges áttekintenünk néhány általános egyezést és eltérést. Közös elem ugyan a két müben a hat istennő alakja, ám leírásaikban, és számos egyéb ponton is találunk eltéréseket. A Genealogia egy alapos filológiai munka eredményeként, a források összegyüjtésének, rendszerezésének és azok többszintü értelmezésének előtérbe állításával megírt munka, amelyben Boccaccio nem csupán megnevezte a forrásait és idézett belőlük, hanem azok allegorikus, történelmi, morális és anagogikus magyarázatait is igyekezett adni. A pontos hivatkozások pedig nem csak lehetővé tették számára az esetlegesen több istennő elkülönítését, hanem szükségessé is, bár ez nem minden esetben sikerült tökéletesen, ahogyan az Ceres példája kapcsán később nyilvánvalóvá fog válni. Nem szabad továbbá szem elől tévesztenünk azt a tényt sem, hogy Boccacciónak a Genealogia szerzőjeként, és ezáltal az antik források elemzőjeként és feldolgozójaként a középkor két értelmezési hagyományát kellett szintetizálnia: az istenek emberi voltát hangsúlyozó

2 Boccaccio műveinek kronológiája ugyan számos ponton kétségeket vet fel, ám mégis az tünik valószínünek, hogy három nagy, latin nyelvü prózai múvét a következő sorrendben írta meg: De casibus virorum illustrium (Híres férfiak bukásairól), Genealogia deorum gentilium (A pogány istenek genealógiája), De mulieribus claris (Híres hölgyekről). Vö. Vittorio ZACCARIA, Boccaccio narratore, storico, moralista e mitografo, Firenze, Olschki, 2001, 1.; Victoria KIRKHAM, Chronology of Boccaccio's Life and Works = Boccaccio: A Critical Guide to the Complete Works, eds. Victoria KIRKHAM, Michael SHERBERG, Janet LEVARIE SMARR, Chicago, The University of Chicago Press, 2013, xvi-xix.; The Cambridge Companion to Boccaccio, eds. Guyda ARMStrong, Rhiannon DANIELS, Stephen J. Milner, Cambridge, Cambridge University Press, 2015, xxxix-xxxv. 
euhémerosi elemzést és az antik isteneket „családfáját" megalkotó genealógiai rendszerezést. ${ }^{3}$ A különböző hagyományok mellett számos olyan körülmény érvényesült, amelyek az egyik legnagyobb kihívássá tették Boccaccio számára eme nagyszabású mü megírását, amely 15 könyvben, 723 fejezetben, több mint 1000 idézetet hozva 200-nál is több görög, római és középkori szerzőtől, 950 mitológiai alakot tárgyal. ${ }^{4}$

Egyrészt ahhoz, hogy megalkossa rendszerét, a latin nyelvü források áttekintése mellett szüksége volt a görög irodalmi források feldolgozására is. Ezt egyfelől barátja, Leonzio Pilato segítségével tudta megtenni, akinek nyelvtudása szintén nem volt megfelelő szintü, ám lényegesen meghaladta Boccaccióét. Ám nem ritkán hivatkozott görög irodalmi forrásra annak latin fordítását felhasználva. ${ }^{5}$ Másrészt a genealógiai rendszerezés miatt Boccacciónak a lehető legalaposabb filológiai munkát kellett végeznie, minden szereplőjének mitológiai hátterét fel kellett kutatnia ahhoz, hogy bekerülhessenek a gyưjteménybe. Amennyiben ezt nem tudta kivitelezni, arra kényszerült, hogy bizonyos mitológiai szereplők említését mellőzze.

Így történt ez Pyramus és Thisbe esetében is, akiknek mivel szüleiről nem sikerült irodalmi forrást találnia, kizárni kényszerült őket a Genealogiából. Ezen a ponton pedig a Genealogia és a De mulieribus között egy jelentős kapcsolódási pont teremthető. Ami nem kaphatott helyet a Genealogiában, az bekerülhetett a De mulieribusba, hiszen utóbbiban az egyetlen teljesítendő feltétel a női szereplő megléte volt a történetben, egyéb szigorú kötöttségek nem korlátozták a gyüjteménybe illesztést. Erre példa Pyramus és Thisbe története, amely a De mulieribus claris tizenharmadik életrajzában olvasható, De Tisbe babilonia virgine címen, ahol a fiatalok szüleinek neve valóban nem kerül említésre, ám ez ezúttal nem jelent kizáró okot. $^{6}$

${ }^{3}$ Jon SOLOMON, Gods, Greeks, and Poetry (Genealogia deorum gentilium) = Boccaccio: A Critical Guide to the Complete Works, eds. Victoria KIRKHAM, Michael SHERBERG, Janet LEVARIE SMARR, Chicago, The University of Chicago Press, 2013, 235-238.

4 Giovanni BoccAccio, Genealogy of the Pagan Gods, Books I-V, ed., transl., Jon SOLOMON, Cambridge, MA, Harvard University Press, 2011 (The I Tatti Renaissance Library, 46), vii.

5 A különböző, latin és ógörög nyelvű források felhasználásáról 1. Jean SEZNEC, $L a$ sopravvivenza degli antichi dei, Venaria Reale, Bollati Boringhieri, 2008, 268-269.

6 Pyramus és Thisbe történetének legvalószínúbb forrása Ovidius Metamorphosese (Ov. Met. IV, 55-166), ahol szintén nem találunk a szülőkre vonatkozó információkat. 
Ezen a ponton szükséges visszatérnünk a források megnevezésének, és ezáltal a két mű között fennálló különbségeknek a tárgyalására. Hiszen, ahogyan az az Előszó és a Johanna nápolyi királynő udvarában befolyásos Andrea Acciaiuolinak szóló Ajánlás alapján feltételezhető, az elsősorban a női olvasóközönségnek írt De mulieribusban két kivételtől ${ }^{7}$ eltekintve Boccaccio nem nevezi meg a forrásait, pedig a Genealogia megírásakor már azok jelentős részét összegyưjtötte, így rendelkezésére álltak.

Ehelyett ilyen és ehhez hasonló megjegyzésekkel vezeti be az új információkat: „Egyes szerzők szerint;” „Némelyek úgy hiszik;” „Mások viszont megerősítik." Ez többek között lehetőséget adott arra, hogy minden, megemlíteni kívánt információt egy életrajzba gyűjtsön, és esetlegesen ne terhelje olvasóit túl sok névvel, vagy a forrásként szolgáló szerzők ne szorítsák háttérbe a híres vagy hírhedt tette miatt kiemelt nőalakot, vagyis a narráció előtérbe kerüljön a szisztematikusan végrehajtott rendszerezéssel szemben. Végül felmerülhet lehetséges indokként, hogy a források beillesztésében halála akadályozta meg Boccacciót, ám mivel ezt a több, mint egy évtizeden át tartó munka során a fentebb említett két esetet leszámítva egyáltalán nem tette meg, így ennek valószínüsége igen csekély.

A másik különbség, hogy a Genealogiában korábban egymástól elkülönített istennők alakjait a De mulieribusban egy-egy életrajzban említi. Ugyan nem egyszer tesz utalást arra, ha értesülései szerint több nőt kell az olvasónak sejtenie az adott istennő mögött, ám tetteik, tulajdonságaik alapján történő elkülönítésüket nem hajtja végre. Minerva esetében Boccaccio olyannyira nyitva hagyja a több feltételezett Minerva létét, hogy az erre vonatkozó állítás az életrajz zárásaként, legutolsó mondataként hangzik el. Az istennőről szóló mondanivalóját azzal zárja, hogy nem kevés jelentős ember állítása szerint az általa fentebb elmondottak nem egy Minervának tulajdoníthatóak, amivel ő szívesen egyetért, hogy ezáltal is növelje a híres hölgyek számát. ${ }^{8}$

\footnotetext{
7 Lycophront nevezi meg Penelope (XXXVIII) életrajzának egyik forrásaként, Szent Jeromos neve pedig Cornifitia tetteinek leírásában (LXXXIV) kerül említésre.

8 Sunt tamen non nulli gravissimi viri asserentes non unius Minervae, sed plurium que dicta sunt fuisse comperta. Quod ego libenter assentiam, ut clare mulieres ampliores sint numero. (De mulieribus VI.) A müből származó valamennyi idézet forrása az alábbi kritikai kiadás: Giovanni BOCCACCIO, De mulieribus claris, a cura di Vittorio ZACCARIA, Milano, Mondadori, 1967 (Tutte le opere di Giovanni Boccaccio, X).
} 
A szándékosan nyitva hagyott kérdések, a meg nem nevezett szerzőkre történő homályos utalásokkal teli mondatok okát ismét csak feltételezhetjük, de talán abban rejlik, hogy míg a Genelogia a lehető legpontosabb, és ebből adódóan forrásokkal alátámasztott családfa megalkotását és az antik irodalmi források rendszerezéssel egybekötött értelmezését tűzi ki célul, addig a De mulieribus magukat a tetteket helyezi előtérbe. Az eltérő célok pedig eltérő szerzői hozzáállást és különböző narrációs elemek használatát igényelték. Hiába volt Boccaccio tisztában számos információval az istennőkkel kapcsolatban, hiszen azokra már mind szert tett a Genealogia megírásakor végzett filológiai kutatásai alkalmával, mégsem állt szándékában bonyolult származási összefüggéseket feltárni a hölgyéletrajzokban, ismert felmenőik alapján elkülöníteni az egyes nőalakokat. Hiszen, ha így tett volna, azzal elhomályosította és háttérbe szorította volna magukat a tetteket, amelyek miatt a művet megírta, ezáltal pedig eltért volna a mü előszavában megfogalmazott célkitüzéseitôl. ${ }^{9}$

Hasonlóságként említhető azonban az istennők ábrázolásában a Szent Ágostontól és Lactantiustól megismert, euhémerosi alapokon nyugvó felfogás, amely szerint az antikvitás istenei és istennői valójában közönséges földi halandók voltak, akiknek a köztudat kivételes, társadalmat előrevivő tetteik miatt tévesen isteni mivoltot tulajdonított. Boccaccio ezt az egyes istennők valamennyi leírásában igyekszik bizonyítani, nem csupán irodalmi forrásaira támaszkodva, hanem a saját magyarázataiban is megerősítve azt. Ez a hozzáállás tudatos Boccaccio részéről, hiszen teljes mitológia-felfogása erre az elvre épül, a műveiben jelenlévő euhémerosi hatás egyfajta mitologia cosmologicaként értelmezhető.

\section{Ceres alakja a Genealogiában}

Ceres (vagy Demeter), aki a görög-római mitológiában a földművelés, a gabona istennője, valamint a termékenység allegorikus alakja volt, önálló leírásban kétszer jelenik meg a Genealogiában (III, 4 és VIII, 4), illetve említés

9 Az Előszóban Boccaccio egyértelműen a gyüjteménybe bekerülő nők tetteire helyezi a hangsúlyt. Arról értekezik, hogy legnagyobb megdöbbenésére a nőknek, annak ellenére, hogy számos kiváló cselekedetet hajtottak végre, mégsem szenteltek teljes egészében irodalmi müvet. Ezért döntött úgy, hogy megemlékezik kivételes nők tetteiről, és általuk követendő példákat állít női és férfi olvasói elé egyaránt. 
szintjén több alkalommal is, ${ }^{10}$ többek között a bizonyos források által férjeként feltételezett Sycanus alakjának (X, 62), valamint lányának, Proserpinának (XI, 6) bemutatásában szerepel. ${ }^{11}$

A Genealogia III, 4-ben (De Cerere prima, Celi III filia, que peperit Acherontem) az első Ceresnek, vagyis Caelum harmadik gyermekének és Acheron anyjának említése során Boccaccio középkori irodalmi forrásokra támaszkodik. Lactantiusra (Inst. I, 14) hivatkozva mondja el, hogy Ceres Caelum és Vesta gyermeke. A fejezet legnagyobb részének forrása Theodontius, aki alapján azt közli, hogy Ceres Sycanusnak, Szicília legősibb királyának volt a felesége, akitől több gyermeke is született, ám közülük forrása egyet sem nevezett meg, ${ }^{12}$ további forrásokat pedig erre vonatkozóan nem hoz. Továbbra is Theodontiusra hivatkozva mondja el, hogy Ceres volt az, aki megtanította a földmüvelést az embereknek, és ugyanezen forrásán keresztül Pronapidesre hivatkozva írta le Boccaccio Acheron történetét. ${ }^{13}$

10 Ceres, Caelum és Vesta gyermeke a III, 4-ben található önálló leírása mellett az alábbi szöveghelyeken szerepel: III, 5; IV, 1. A további, másik Ceresre vonatkozó utalások a Genealogiában: I, 8 (Saturnus és Ops lánya); II, 51 (Luna); III Proh; III, 13; IV, 16; V, 25; V, 26 (Eleusisi Ceres); VIII, 3; VIII, 6; X, 62; XI, 6; XI, 13; XII, 1-3.

11 Dicit tamen Theodontius, huius Cererem fuisse coniugem et Proserpinam filia, quam Iovis dicere poete. (Genealogia X, 62). A müből származó valamennyi idézet forrása az alábbi kritikai kiadás: Giovanni BOCCACCIO, Genealogia deorum gentilium, a cura di Vittorio ZACCARIA, Milano, Mondadori, 1998 (Tutte le opere di Giovanni Boccaccio, VII-VIII).

12 Ceres, ut placet Lactantio in libro Divinarum istitutionum, filia fuit Celi et Veste. Hanc dicit Theodontius Sycani, vetustissimi Sycilie regis, fuisse coniugem, Syculosque primam frumenti usum docuisse et Sycano plures peperisse filios, nullum tamen nominat. (Genealogia III, 4).

13 A történet Boccacciónál szereplő változata szerint az állapotos Ceres szégyenében Kréta szigetén rejtőzött el, majd ott titokban, egy barlang mélyén adott életet gyermekének, Acheronnak. A gyermek egész életében magán viselte a rejtőzködéssel járó megaláztatás és szégyen nyomait, így nem mert a fényre jönni. Ezt nevének etimológiája is magában hordozza, magyarázza Boccaccio, aki ógörög etimologizálásainak túlnyomó részét barátjának, Leonzio Pilatónak köszönheti. A leírásban szereplő magyarázat szerint ugyanis az Acheron görögül annyit jelent, hogy öröm nélküli ( $a=$ sine; cheron = gaudium; az ógörögben $\dot{\alpha} \chi \varepsilon v ́ \omega=$ szomorkodik). Fájdalmában a fiúgyermek a földre szegezte a tekintetét, később pedig a föld alá rejtőzött, így lett az Alvilág egyik folyója. A történet Theodontius és Pronapides okfejtésével is kiegészül, miszerint Acheron eleve bánatra és fájdalomra volt ítélve, hiszen maga Ceres is a titánok harca idején testvére fogságba esése miatti bánatában foganta a Fájdalmat, akinek aztán később életet adott, és akinek apát nem szokás tulajdonítani, mivel képzeletünkben fogant. 
Ebből adódóan a következő fejezetből, a fiának tartott Acheron leírásából (De Acheronte infernali fluvio Cereris filio, qui genuit VI filios scilicet Alecto, Thesiphonem, Megeram, Victoriam, Aschalapum et Stygem; III, 5) sem hiányozhat Ceres alakja, ám itt csak megerősítésre kerül az az információ, hogy őt tartják számon az Alvilág folyójának anyjaként, ${ }^{14}$ új ismeretet nem közöl róla Boccaccio. Ceres következő, ismételten említés szintjén történő megjelenésére a IV, 1-ben (De Titano Celi filio VIII ...) fivére, Titanus leírásában kerül sor, ahol a két testvér, Saturnus és Titanus uralkodásról szóló megállapodása kapcsán olvashatjuk, hogy Ceres és Ops azt tanácsolták Saturnusnak, ne engedje át az uralmat bátyjának. ${ }^{15} \mathrm{Ez}$ azonban nem először elhangzó információ, helyet kapott ugyanis a Genealogia III, 4-ben is, a testvérek harcának rövid leírásával együtt.

Ceres második, önálló említése során a Genealogiában (De Cerere III Saturni filia et matre Proserpine; VIII, 4) Boccaccio kihangsúlyozza, hogy a korábbiakban említett Cerestől különböző alakról van szó, akinek a fejezetben gabonaistennői mivolta és Jupitertől született lányának, Proserpinának elrablása kerülnek hangsúlyozásra, ám ezeken kívül számos egyéb ismeretet is közöl róla. Ebből a fejezetből kiderül, hogy Saturnus és Ops lánya, ${ }^{16}$ akinek anyaként szembe kellett néznie lánya elrablásával, amelynek körülményeit, az általa feltalált mezőgazdasági eszközök összetörését, a lány hosszas keresését és megtalálását Boccaccio részletesen ismertette a fejezetben. Ezt Lactantiusra ${ }^{17}$ hivatkozva ki is egészíti Triptolemus történetével, akit állítólag Ceres, aki lánya keresése közben Eleusisba ${ }^{18}$ is eljutott, dajkaként, napközben isteni tejjel táplálva, éjszakánként pedig tüzbe tartva halhatatlanná akart tenni, ám ezt túlságosan kíváncsi apja meghiúsította. Ovidius szerint azonban Triptolemus egy szegény, beteg gyermek volt, akit Ceres meggyógyított.

Boccaccio az Odysseiának, és főként görögül tudó barátjának, Leonzio Pilatónak köszönhetően említi meg azt a történetet, amely szerint Ceres

\footnotetext{
${ }^{14}$ Cur Cereris dictus sit filius premonstratum est. (Genealogia III, 5).

${ }^{15}$ sorores Ceres atque Ops suadent Saturno uti de regno non cedat fratri (Genealogia IV, 1).

${ }^{16}$ Ezt Ovidiusra (Ov. Fast. VI, 285) hivatkozva írja le Boccaccio: Saturni filia atque Opis, ut ab Ovidio supra monstratum est

17 In Statii Thebaida II, 382.

18 Narrant insuper, et inter alios Lactantius, quod cum perquirens Ceres filiam ad Eleusium regem pervenisset... (Genealogia, VIII, 4).
} 
beleszeretett Iasionba, akitől gyermeke is született, Plutus, a gazdagság istene. Iasiont azonban Jupiter mérgében halálra sújtotta villámával. ${ }^{19}$

A különféle történetek összegyüjtése után Boccaccio azok magyarázatát tárja olvasói elé. Ezek között különös figyelmet érdemel az, amelyben Theodontiusra hivatkozva kifejti, hogy Ceres valójában ember volt, földi halandó, nem pedig egy istennő, ahogyan azt tévesen a régi korok emberei hitték, Sycanus felesége, aki rájött arra, hogyan kell megmüvelni a földet, ezt pedig kész volt megtanítani alattvalóinak, akik korábban gyüjtögetéssel szerezték a mindennapi betevőjüket. ${ }^{20}$ Azonban, ha visszagondolunk az első Ceres-leírásra, feltűnik az a következetlenség, hogy ezeket az információkat az első Ceres kapcsán egyszer már leírta Boccaccio, így ezt a Theodontius-szöveghelyet másodjára használta fel. További ellentmondásba keveredett, amikor Proserpina apjaként egyszer Jupitert (VIII, 4), másszor pedig Sycanust $(X, 62)$ nevezte meg, ám amikor Thedontiustól idézett a III, 4-ben, azt állította, hogy Sycanus és Ceres egyetlen közös gyermekének neve sem ismert. Mégis ez, a férjére vonatkozó visszatérő elem tekinthető a leghangsúlyosabbnak, ugyanis a harmadik megjelenése is Sycanus feleségeként említi Cerest a Genealogiában, megnehezítve ezzel az egyes Ceresek elkülönítését.

Ezek tehát azok a források és ismeretek, amelyek egészen biztosan Boccaccio rendelkezésére álltak a De mulieribus megírásakor. ${ }^{21}$ De mennyit és milyen részletességgel épített be belőlük? Esetleg újakkal is kiegészítette őket? A kérdést minden kétséget kizáróan nem lehet megválaszolni, hiszen Boccaccio a De mulieribusban nem nevezi meg a felhasznált forrásait, így

\footnotetext{
19 Sunt insuper qui dicant, et Omerus potissime in Odissea, Cererem Iasionem quendam amasse, et sese illi amicitia et lecto iunxisse. Et Leontius addebat Cererem ex Iasione Plutonem filium peperisse, et tandem Iasionem a Jove invidia fulminatum. (Genealogia, VIII, 4).

20 Theodontius ex Cerere ista vetustissimam refert hystoriam, ex qua videtur multum cause fictionis superioris assumptum, et dicit: Cererem Saturni filiam Sycani regis fuisse coniugem, et Sycilie reginam, ingenio clarissimo preditam. Que cum per insulam cerneret homines vagos glandes et mala silvestria comedentes, nec ullis obnoxios legibus, prima in Sycilia terre culturam excogitavit, et adinventis instrumentis ruralibus boves iunxit, et terris semina dedit, ex quo homines cepere inter se campos dividere, et in unum convenire, et humano ritu vivere (Genealogia, VIII, 4). A szöveghely lehetséges forrása Ovidius (Ov. Met. V, 341-343).

${ }^{21}$ Boccaccio müveinek kronológiájáról 1. a 2. lábjegyzetet.
} 
felhasználásukra főként a szóhasználatból és az információk azonosságából következtethetünk.

\section{Ceres alakja a De mulieribus clarisban}

Boccaccio a De mulieribus claris ötödik életrajzát szentelte Ceresnek, amelyben szintén megjelenik az euhémerosi elképzelés, miszerint Ceres alakja mögött nem egy istennőt kell sejtenünk, ahogyan azt az antik források tartják, ${ }^{22}$ hanem egy szicíliai királynőt. Ô volt az, aki feltalálta az ekét, az ekevasat, a földmüvelést, a barmok igába hajtását, valamint a gabona feldolgozásának és a kenyér készítésének módját, majd mindezeket megmutatta a korábban gyưjtögetésből élő alattvalóinak, akik hálából istennőként kezdték tisztelni, Saturnus és Cybele lányának tartották.

A leírás következő eleme Proserpina elrablása tényének említése, ám annak hosszas és részletes leírásába ez alkalommal nem bocsátkozik. Csak annyit közöl, hogy Ceresnek fivérétől, Jupitertől született egy Proserpina nevű lánya, akit anyja nagy szomorúságára Orcus elrabolt, és akit sokáig keresett. Ez az eset pedig számos történet születéséhez vezetett, ${ }^{23}$ ám ezek felsorolása és kifejtése elmarad.

Az, hogy Orcust nevezi meg Proserpina elrablójaként, számos lehetséges forrást feltételez, és egyben szemlélteti azok megállapításának nehézségeit. A szóhasználatból a következő szerzők ismeretére lehet következtetni. A névalak, a Genealogia tanúsága szerint, lehet utalás Theodontiusra, akire hivatkozva Boccaccio a VIII, 4-ben leírja, hogy Orcus rabolta el Ceres lányát. Ugyanebben a leírásban ezt követően Boccaccio hozzáteszi, hogy ez az információ Eusebiusnál ${ }^{24}$ is megtalálható, tehát az ő művében is olvashatta, vagy találhatott rá utalást más szerzőnél. De a

\footnotetext{
${ }^{22}$ Nem nevezi meg ugyan sem Ovidiust, sem Vergiliust, de szinte biztosan rájuk utal. A fejezet forrásául szolgálhatott a Metamorphoses (Ov. Met. V, 341-571), valamint a Georgica (Verg. Georg. I, 7-8 és I, 160-161). Nem zárható ki annak lehetősége, hogy Ovidius nevét azért nem említi meg a Genealogiában sem, mert művéből közvetetten, Lactantius alapján hivatkozik. Vö. SEZNEC, i. m., 269.

${ }^{23}$ Huic preterea unicam ex Iove fratre fuisse filiam Proserpinam dicunt eamque maxima matris turbatione ab Orco Molossorum rege raptam et diu quesitam volunt, multis hinc fabulis occasionem prebentes. (De mulieribus claris $V$ ).

24 Eus. Chronicon XLXIX, 19-20.
} 
Genealogia VIII, 6 alapján akár Cicerót ${ }^{25}$ is használhatta. A névalakot tehát számos forrásból ismerhette Boccaccio, ahogyan azt a Dante Szinjátékának magyarázatául készített Esposizioni sopra la Commedia (VIII, 6) ${ }^{26}$ vagy Szent Ágoston De civitate Dei c. múve is tanúsítja (Aug. Civ. Dei VII, XX). ${ }^{27}$ Ezeken kívül az Orcus névalak elöfordul a Mythographus Vaticanusban ${ }^{28}$ is. Mivel a szerző őt nevezi meg Proserpina elrablójaként, ezáltal ez a mü is a fejezet egy lehetséges forrásának tekinthető. Már egyetlen névalak Boccaccio számára elérhető irodalmi megjelenéseinek vizsgálatából is kiderül, hogy milyen összetett a De mulieribus forráshasználatának kérdése, és hogy nem egyszerüsíthető le az istennők esetében sem arra, hogy Boccaccio a Genealogiában összegyüjtött ismereteit egyszerüen átemelte.

Az elrablás említését követően megtudhatjuk, hogy a hagyomány egy másik, eleusisi Ceres létét is feltételezi, akit hasonló tettei miatt tiszteltek. Ám Boccaccio, ahogy a De mulieribusban többször, ${ }^{29}$ ezúttal is úgy dönt, hogy a két személyt egy életrajzban tárgyalja, a velük kapcsolatos információkat összevegyíti. Választását ebben a fejezetben röviden azzal indokolja, hogy ezt a megoldást elegendőnek találta. ${ }^{30}$ Alakjának ismét több forrása valószínüsíthetö, ugyanis az eleusisi Ceres megjelenik a Genealogia VIII, 4-ben (Triptolemus neve ott is szerepel, akárcsak a De mulieribus jelen fejezetében), a második Ceresnek szentelt életrajzban, ahol Lactantius Placidust ${ }^{31}$ (In Statii Thebaida II, 382) idézi, valamint a már idézett ágostoni szöveghely (Civ. Dei

\footnotetext{
${ }^{25} \mathrm{Az}$ Esposizioniban is idézett cicerói szöveghelyet hozza a Genealogia VIII, 6-ban is, Pluto leírásában, ám kiegészíti azzal, hogy ugyanígy nevezi az istent Rabanus Maurus is: Quem ideo sic vocari dicit Rabanus.

${ }^{26}$ Verres alter Orcus venisse Hennam et non Proserpinam asportasse sed ipsam abripuisse Cererem videretur. (Cic. Verr. IV, 111.).

27 quod filiam Cereris, id est ipsam fecunditatem, quae a proserpendo Proserpina dicta esset, Orcus abstulerat et apud inferos detinuerat (Aug. Civ. Dei VII, XX).

${ }_{28}$ Ceres cum raptam a Plutone Proserpinam filiam diu quaesisset, tandem aliquando eam esse apud inferos comperit, quia a Plutone, siue Orco, fratre Iouis rapta fuerat. (I, 1 Fabula Cereris et Proserpinae).

${ }^{29}$ Vö. a De mulieribus alábbi életrajzaival: De Minerva; De Venere.

${ }^{30}$ sub uno nomine ambarum ingenia retulisse satis visum est (De mulieribus V.).

${ }^{31}$ Narrant insuper, et inter alios Lactantius, quod cum perquirens Ceres filiam ad Eleusium regem pervenisset... (Genealogia, VIII, 4.).
} 
VII, XX ${ }^{32}$ is tartalmaz az eleusisi misztériumokra vonatkozó információkat. Misztériumait megemlíti továbbá Boccaccio az Esposizioni sopra la Commediában (VI, 9) ${ }^{33}$ is.

A források megnevezésének hiányában Boccacciónak megváltozott narrátori hozzáállásra volt szüksége az egyes leírások lezárásához, ugyanis nem volt lehetősége az életrajzokat forrásai többszintü értelmezésével zárni, vagyis ezen a ponton ismét el kellett térnie a Genealogiától. A De mulieribusban

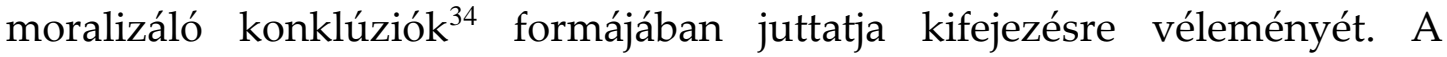
Ceresről közölni kívánt ismeretek leírása után, amely a teljes életrajzból fél oldalt foglal el, - annak ellenére, hogy a Genealogiában összesen ötoldalnyi ismeretet gyüjtött össze róla, - rátér a kétoldalnyi terjedelmü ${ }^{35}$ moralizáló konklúzióra. Ebben arról értekezik, hogy nem tud egyértelmű ítéletet hozni azzal kapcsolatban, hogy előrevivő, avagy inkább hátráltató volt az emberiség számára a földmüvelés feltalálása. ${ }^{36}$ Hiszen annak ellenére, hogy hozzájárult egyfajta fejlődéshez, az emberiségnek jobb életet és civilizációt hozott, számos negatív következménnyel járt. Magával hozta a köztulajdon megszűnését, és az ezzel járó tulajdonjogi vitákat, az enyém-tied viszályokat, a földmüveléssel járó fáradságos munkát, a földek körbekerítését, valamint számos negatívumot, az éhezést, a kapzsiságot, a háborúkat, az irigységet, a

\footnotetext{
32 quia rursus eadem fecunditas rediit, Proserpina reddita exortam esse laetitiam et ex hoc sollemnia constituta. Dicit deinde multa in mysteriis eius tradi, quae nisi ad frugum inuentionem non pertineant. (Aug. Civ. Dei VII, XX.).

33 „Ma, poi che, per suggestion diabolica, sí come io credo, cominciò tacitamente ne' cuori d'alcuni ad entrare l'ambizione, e quinci il disiderio di trascendere a piú esquisita vita, venne Cerere, la quale appo Eleusia e in Sicilia prima mostrò il lavorío della terra, il ricogliere il grano e fare il pane." (Boccaccio, Esposizioni sopra la Commedia, VI, 9.).

${ }^{34}$ Ezek változó terjedelmüek a müben, néhány sortól egészen két-három oldalig terjedhetnek, de arra is találunk példát, hogy teljesen hiányoznak. Másik jellegzetességük, hogy nem minden esetben kapcsolódnak szorosan az adott fejezethez, Ceres azonban azok közé a példák közé sorolható, amelyekben megvan a kapcsolódás.

35 Érdemes megfigyelni, hogy a kritikai kiadásban két és fél oldal terjedelmű életrajzból csupán fél oldalt tesznek ki a különféle Ceres-történetek, a többi teljes egészében moralizálás. 36 Ceres, a törvények és a társadalom kapcsolatáról 1. Gianluca BRIGUGLIA, Cerere $e$ l'agricoltura. Osservazioni su un mito delle origini in Boccaccio = L'antichità classica nel pensiero medievale. Atti del Convegno della Società Italiana per lo Studio del Pensiero Medievale (S.I.S.P.M.) Trento 27-29 settembre 2010, a cura di Alessandro PALAZZO, Porto, Fédération Internationale des Instituts d'Études Médiévales, 2011, 373-384.
} 
betegséget és a szegénységet is, véget vetve ezzel az aranykornak, és elhozva az ezüstkor kezdetét. Így Ceres alakja azok közé tartozik, akiknek a megítélése Boccaccio részéről egyszerre esik a pozitív, illetve a negatív tartományba, mindkét oldalon számos érv felsorakoztatásával, ám a szerző egyértelmü állásfoglalása nélkül.

\section{Összegzés}

Nagy mennyiségű ismeretanyag állt tehát Boccaccio rendelkezésére Ceresről, ókori görög, latin, valamint középkori irodalmi forrásokból egyaránt, amelyeket mindkét müben céljainak megfelelően, változó terjedelemben fel is használt. Ezek nagyobb részét a Genealogiába illesztette be, hiszen a mü témája, célkitüzése is ezt indokolta. Ugyanis egy, a pogány isteneket rendszerező müben, ahol a lehető legpontosabb adatokra és a legaprólékosabb magyarázatra volt szükség, a De mulieribusban megfigyelhető összevonást nem alkalmazhatta volna. Valamennyi leírást egyértelműen áthat az euhémerosi istenkép, amelynek kapcsán nem zárhatjuk ki annak a lehetőségét sem, hogy követése nem egy tudatos meggyőződés eredménye, csupán a számos változatban fennmaradt történetek rendszerezése végett alkalmazott módszer. Ami pedig a boccacciói leírások alapján a két müben közös jellegként kirajzolódik: Ceres mindkettőben szerepel a földművelés feltalálójaként, a gabona istennőjeként, Proserpina anyjaként, valamint istennői voltát mindhárom leírásban azzal cáfolja meg, hogy Sycanus felesége volt, egy kivételes asszony, aki éles eszének köszönhetően gondoskodott az emberiség előrehaladásáról, vagy éppenséggel találmányával pecsételte meg annak sorsát.

A korszakok és különböző értelmezési keretek határán álló Boccaccio sokszínű és rendkívül változatos irodalmi, filológiai hozzáállásának kiemelkedő példája a két mü. Míg a Genealogiában egy precíz, a filológusi munka mibenlétét megtapasztaló és azt alapjaiban meghatározó Boccaccio alakja jelenik meg, addig a De mulieribusban a történetmesélő, a Dekameron narrátora rajzolódik ki előttünk. Előbbi hozzáállás eredményeként megszületik a filológia, utóbbinak köszönhetően pedig elkészül a nyugati irodalom első nőiéletrajz-gyưjteménye. Különböző célok és hozzáállás találkozása ez, amely tradíció és innováció határán műfajteremtővé teszi Boccacciót és megalapozza helyét az olasz irodalom „három koronája” között. 